\title{
Percutaneous endoscopic sigmoidopexy: a simple procedure within every endoscopist's reach
}

An 87-year-old man with severe co-morbidities (obstructive pulmonary disease and chronic heart failure, among others) and chronic constipation had previous admissions to the hospital six episodes of large-bowel obstruction, including four documented sigmoid volvuli, and two others that were directly treated with placement of a decompression tube. In the year after the emergency endoscopic detorsion, there were ten more episodes. Surgery was ruled out because of his high risk, and the patient underwent percutaneous endoscopic sigmoidopexy ( Video 1).

After a complete colonoscopy and with the patient supine, the first transillumination through the abdominal wall was identified. This coincided with a point located $15 \mathrm{~cm}$ proximal to the torsion of the sigma. Following a $2 \%$ Lidocaine injection and incision, the surgeon punctured the colon wall with a paracentesis catheter ( Fig.1) through the subcutaneous tissue under endoscopic guidance. Next, the inner needle was removed and the blunt-tipped fenestrated catheter left inside for insertion of a suture. When the thread loop was inserted into the colonic lumen, it was caught in a clip by the endoscopist. To confirm that the loop had been securely caught by the clip, the surgeon pulled the suture toward the base of the open clip.Thus, when the clip was closed the thread was firmly caught, as checked in a test before the procedure (> Fig.2). Finally, a subcutaneous suture was made and the incision closed with a short-term absorbable suture (SafilQuick; B. Braun, Melsungen, Germany). Six further distal fixations were made at 5-cm intervals.

The patient was discharged 10 days after the procedure owing to cardiac and pulmonary decompensation. He began oral intake and bowel movements $24 \mathrm{~h}$ and $72 \mathrm{~h}$ after the procedure, respectively. Except for mild abdominal pain, there were no complications. At a 2-month follow-up

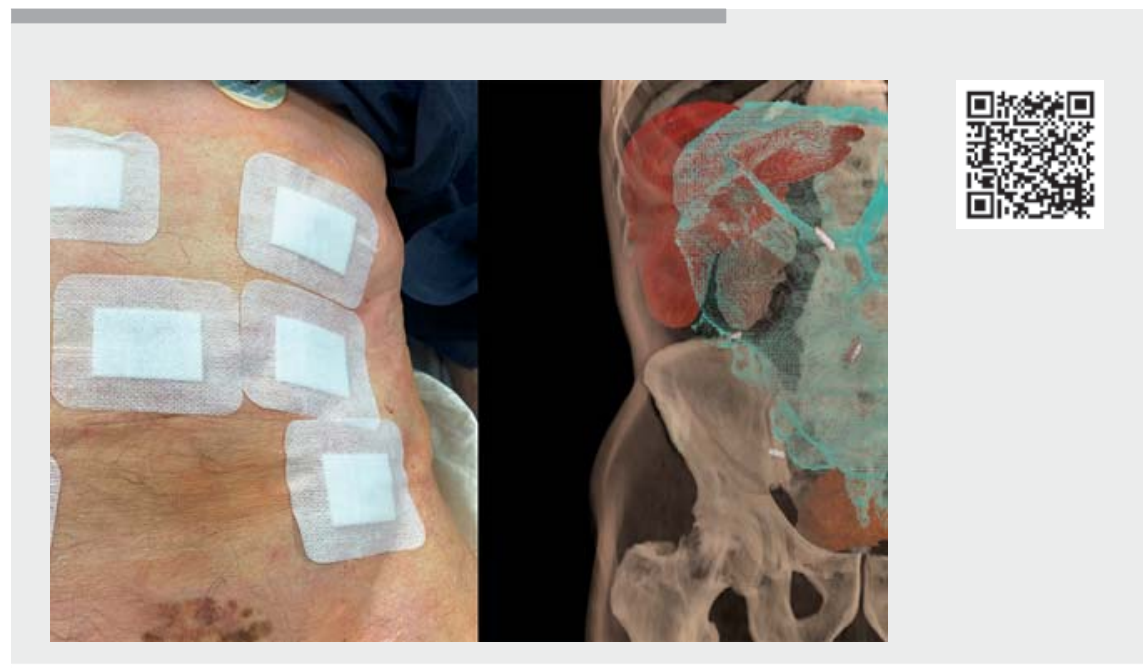

$\checkmark$ Video 1 Percutaneous endoscopic sigmoidopexy.

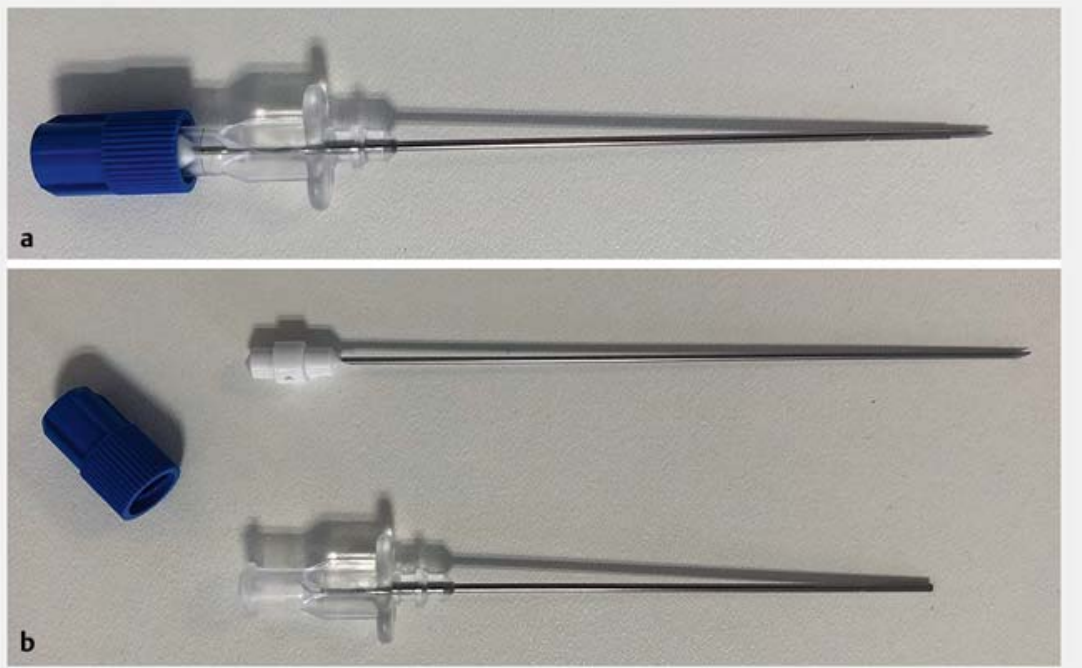

- Fig. 1 a Paracentesis catheter. b Inner needle and blunt-tipped fenestrated catheter.

computed tomography (CT) scan, adequate colon fastening to the abdominal wall was confirmed. He had suffered no recurrences 5 months post-procedure.

Currently percutaneous endoscopic sigmoidopexy is an accepted treatment for recurrent sigmoid volvulus in patients like ours [1,2]. Consequently, we propose a method of percutaneous endoscopic sigmoidopexy that is likely as effective as that described by Imakita [3] although more accessible.

Endoscopy_UCTN_Code_TTT_1AQ_2AF 


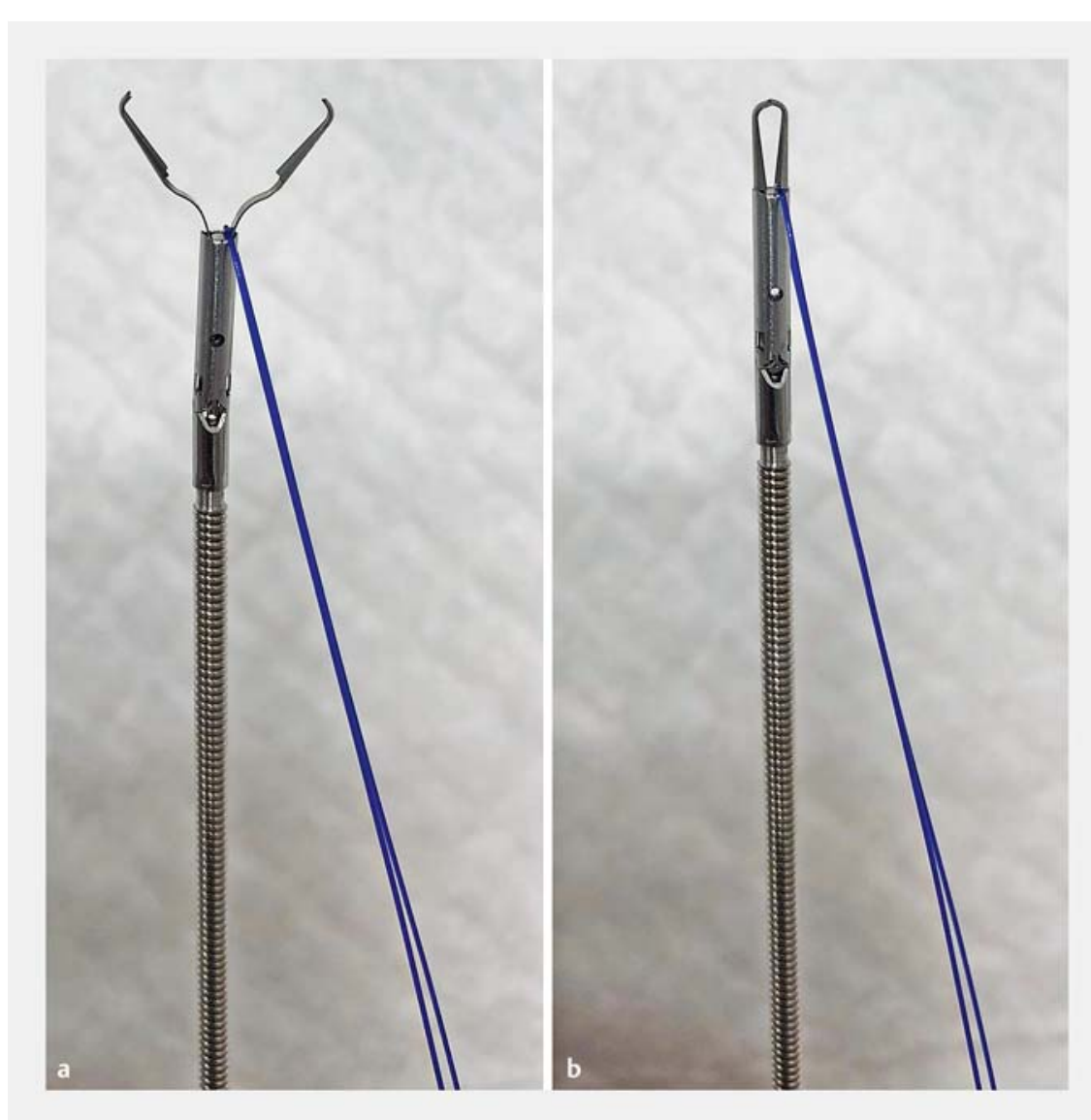

- Fig. 2 Resolution 360 clip (Boston Scientific) and 2/0 polypropylene-polyethylene monofilament (Optilene, Braun). a The suture thread loop has been pulled back to the base of the open clip. b The thread loop is firmly caught when the clip is closed.

\section{Competing interests}

The authors declare that they have no conflict of interest.

The authors

Marco Alburquerque Miranda ${ }^{1,2}$, Miquel Gomez Artacho ${ }^{3}$, Alba Vargas García ${ }^{1,2}$, Gemma García Continente ${ }^{4}$, Cesar Ledezma Frontado ${ }^{1}$, Montserrat Figa Francesch ${ }^{2}$, Ferrán González-Huix Lladó5, 2

1 Department of Gastroenterology, Hospital de Palamós, Girona, Spain

2 Department of Gastroenterology, Clínica Girona, Girona, Spain

\section{References}

[1] Naveed M, Jamil L, Fujii-Lau L et al. American Society for Gastrointestinal Endoscopy guideline on the role of endoscopy in the management of acute colonic pseudo-obstruction and colonic volvulus. Gastrointest Endosc 2019; 91: 1-8

[2] Vogel JD, Feingold DL, Stewart DB et al. Clinical practice guidelines for colon volvulus and acute colonic pseudo-obstruction. Dis Colon Rectum 2016; 59: 589-600

[3] Imakita T, Susuki Y, Ohdaira H et al. Colonoscopy-assisted percutaneous sigmoidopexy: a novel, simple, safe, and efficient treatment for inoperable sigmoid volvulus. Gastrointest Endosc 2019; 90: 514-520

Bibliography

Endoscopy 2021; 53: E470-E471

DOI 10.1055/a-1346-8156

ISSN 0013-726X

published online 4.2.2021

(c) 2021. Thieme. All rights reserved.

Georg Thieme Verlag KG, Rüdigerstraße 14,

70469 Stuttgart, Germany

\section{ENDOSCOPY E-VIDEOS}

https://eref.thieme.de/e-videos

回回 Endoscopy E-Videos is a free access online section, reporting 靣舴: on interesting cases and new techniques in gastroenterological endoscopy. All papers include a high quality video and all contributions are freely accessible online.

This section has its own submission website at https://mc.manuscriptcentral.com/e-videos

\section{Marco Alburquerque Miranda, MD}

Department of Gastroenterology, Hospital de Palamós, 36 Hospital St., Palamós -

Girona 17246, Spain

nictalope7@gmail.com 